\title{
Growth and Production of Leaves Thalassia hemprichii on The Suli Coastal Waters, Ambon Island
}

\author{
Charlotha Irenny Tupan ${ }^{1}$, Prulley Anette Uneputty ${ }^{2}$
}

\begin{abstract}
The aims of this study were to analyze the growth rate, production and biomass of Thalassia hemprichii leaves on different substrates in Suli coastal waters, Ambon Island. Data were collected at muddy substrate and sandy substrate by using tagging method. Tagging was applied weekly to 30 seagrass shoots for one month on each station. The growth rate of Thalassia hemprichii leaves ranged from $0.27 \pm 0.45$ to $0.46 \pm 0.53 \mathrm{cmday}^{-1}$. Production ranged from 5.08 to $^{8.64} \mathrm{gADWm}^{-2} \mathrm{day}^{-}$ 1 and the biomass ranged from 245 to $541 \mathrm{gADWm}^{-2}$. The growth and production of $T$. hemprichii leaves is higher in sandy substrates than in muddy substrates.
\end{abstract}

Keywords — seagrass, growth rate, biomass, substrate, tagging

\section{INTRODUCTION}

$\mathrm{S}$ important role in the life of various marine life. In addition, it is also one of the most productive marine ecosystems. The importance of the existence of seagrass beds in the waters is not only related to its role as supporting fishery production, but it is also its physical function and biochemical content. Seagrass beds acts as primary producers, bottom seabed stabilizers and coastal erosion prevention, food sources, nurseries and shelter for some organisms. Seagrasses also have potential as a raw material of paper, food and medicine for humans because of its biochemical content [1].

As one of producer in shallow sea waters, seagrass beds have high productivity. According to Mc Roy and Mc Millan [2], primary productivity for certain species in fertile areas can reach $6.825 \mathrm{gCm}^{-2} \mathrm{year}^{-1}$. The production is generally derived from the bottom of the substrate (bellow ground) and the top of the substrate (above ground). Primary productivity derived from below the substrate includes roots and rhizhomes and from above the substrate includes leaves and leave sheath. One of the most prominent aspects of biology and closely related to the productivity of seagrass is growth. High growth rates can produce high productivity as well. Seagrass growth is limited by substrate conditions of the waters. The substrate plays a role in determining the stability of seagrass life, as the medium for growth of the seagrasses so they're not to be carried by currents and waves, as a medium for cycles and nutrient sources. Different types of substrate composition can cause differences in seagrass type composition, may also affect fertility differences and seagrass growth.

Various studies have been conducted to study the growth and productivity of seagrasses and mostly done on the seagrass species Enhalus acoroides. This type of

Charlotha Irenny Tupan, Faculty of Fishery and Marine Science, PattimuraUniversity, Jl. Mr. Chr. Soplanit, Kampus Poka, Ambon, Indonesia.97233, Email: lotjetupan@yahoo.com

Prulley Anette Uneputty, Faculty of Fishery and Marine Science, PattimuraUniversity, Jl. Mr. Chr. Soplanit, Kampus Poka, Ambon, Indonesia. 97233, Email: nonnyune@gmail.com the research is rarely done on the Ambon Island. Besides that, the one of the dominant species of seagrasses and has widespread distribution on Ambon Island is Thalassia. hemprichii. Coastal waters of the village of Suli has a dense seagrass ecosystem with rich or healthy seagrass meadow status where species T.hemprichii is one of the dominant species [3]. The condition of such seagrass, if it doesn't preserved, it will decrease in the future. Recently, various activities occur in the coastal waters of Suli such as waste disposal, sand mining, boat mooring and coastal tourist destinations have the potential to affect the growth of seagrass. If the growth of the seagrass is disturbed, it will lead to a decline. Therefore, the seagrass could loss from the area. The loss of any area of this disturbing will result in the loss of function and benefits of this ecosystem. Even more than that, as consequences the surrounding ecosystem would also affect, because the seagrass is also a producer of energy biomass and various species of animals to the ecosystem of coral reefs and mangroves. This study aims to determine the growth, production and biomass of T.hemprichii seagrass on different substrates in the coastal waters of Suli, Ambon Island.

\section{METHODS}

\section{II.1 Sampling method}

Sampling begins with the determination of sampling sites based on substrate differences and on the monospecific species of $T$. hemprichii seagrass. There were 2 observation stations namely station 1 with the muddy substrate $\left(3^{0} 37^{\prime} 662^{\prime \prime} \mathrm{S}\right.$ and $\left.128^{\circ} 18^{\prime} 384^{\prime \prime} \mathrm{E}\right)$ and station 2 with sandy substrates $\left(3^{0} 37^{\prime} 587^{\prime} ' \mathrm{~S}\right.$ and $128^{0} 18^{\prime} 234^{\prime \prime}$ 'E) (Figure 1). 


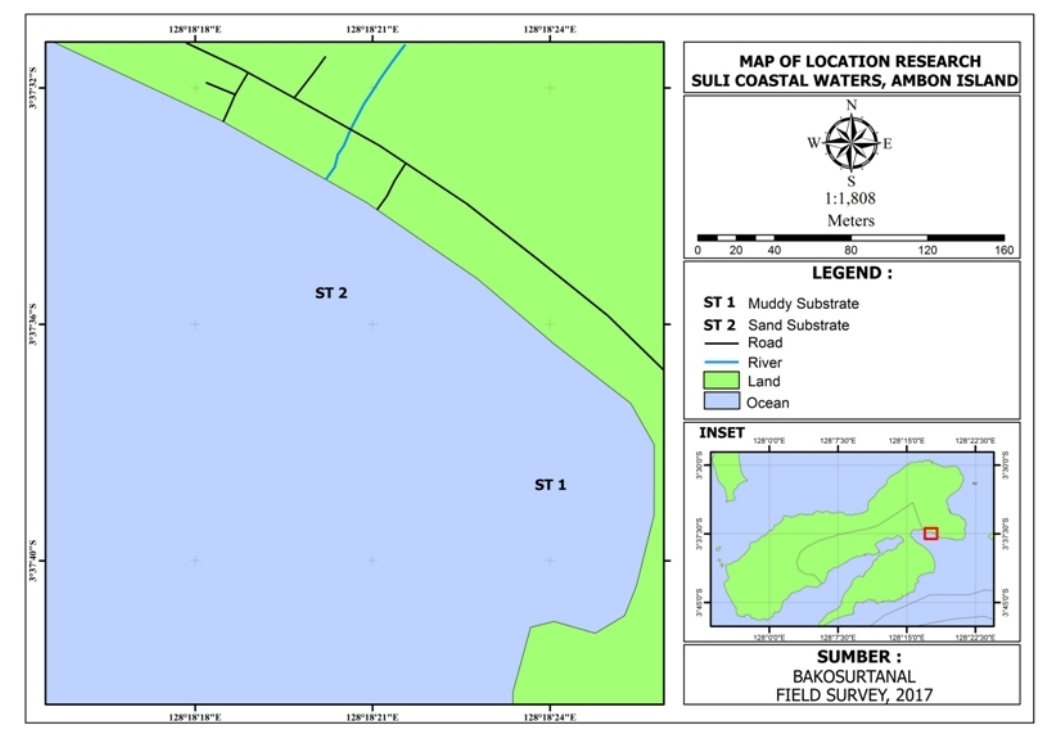

Figure 1. Map of location research

Observations on each station were performed by using 3 plots of $1 \times 1 \mathrm{~m}$ size and placed randomly. The measurement of leaf growth was used the tagging method $[4,5]$. The seagrass leaves were tagged with a paper clip at a height of $3 \mathrm{~cm}$ from the surface of the substrate and mounted a supporting pad which the end of the peg was directly on the paper clip tag. Tagging was done on 30 leaves on each station every week for 1 month. After 1 month (4 weeks) the seagrass shoots were harvested and cleaned from the attaching organism. The length of the leaf that grows was cut and separated from the old leaves. Then, the leaves were dried in the oven at $60^{\circ} \mathrm{C}$ for 24 hours. After that, these were weighed to obtain the dry weight [6]. In order to obtain biomass, the entire leaves and sheath were cut, dried and weighed to obtain dry weight. Some environmental parameters measured were temperature, salinity, $\mathrm{pH}, \mathrm{DO}$ and content of phosphate and nitrate.

\section{II.2 Data Analysis}

Data of Growth, production, biomass and density were calculated according to Short and Coles [7].

\section{(1). Growth}

The growth of $T$. hemprichii leaves was obtained by the formula:

$$
K t=\frac{L t-L 0}{\Delta t}
$$

Where :

\begin{tabular}{|c|c|c|}
\hline $\mathrm{Kt}$ & $=$ & Growth (cm.day $\left.{ }^{-1}\right)$ \\
\hline $\mathrm{T}$ & $=$ & $\begin{array}{l}\text { Length of observation time } \\
\text { (day) }\end{array}$ \\
\hline LO & $=$ & $\begin{array}{l}\text { The initial length of } T \text {. } \\
\text { hemprichii leaf }(\mathrm{cm})\end{array}$ \\
\hline $\mathrm{Lt}$ & $=$ & $\begin{array}{l}\text { End length of } T \text {. hemprichii } \\
\text { leaf at time } \mathrm{t}(\mathrm{cm})\end{array}$ \\
\hline
\end{tabular}

(2). Production

Production is calculated based on the formula:

$\mathrm{Pt}=\mathrm{P} \times \mathrm{D}$

$$
\begin{aligned}
& \text { Where : } \\
& \mathrm{Pt}=\text { Leaf production per area (gADWm- } \\
& { }^{2} \text { day }^{-1} \text { ) } \\
& \mathrm{P}=\text { Production of leaves per shoot } \\
& \text { (gADW.shoot }{ }^{-1} \text { day }^{-1} \text { ) } \\
& \mathrm{D}=\text { Density of } T \text {. hemprichii }\left(\text { shoot. } \mathrm{m}^{-2}\right) \text {. }
\end{aligned}
$$

(3). Biomass

Biomass is calculated by the formula:

$$
\mathrm{B}=\mathrm{W} \times \mathrm{D}
$$

$$
\begin{aligned}
& \text { Where : } \\
& \mathrm{B}=\text { Biomass } \\
& \mathrm{W}=\text { Dry weight of shoot (gADW.shoot } \\
& \text { 1) } \\
& \text { D }=\text { Density of T. hemprichii (shoot.m } \\
& { }^{2} \text { ). }
\end{aligned}
$$

(4). Density

Density of $T$. hemprichii is calculated by the formula

$$
\mathrm{D}=\mathrm{Di} / \mathrm{A}
$$

$$
\begin{aligned}
& \text { Where : } \\
& \mathrm{D} \quad=\text { Density of } T \text {. hemprichii }\left(\text { shoot. } \mathrm{m}^{-2}\right) \text {. } \\
& \text { Di }=\text { Number of shoot T. hemprichii } \\
& \text { (shoot) } \\
& \text { A } \quad=\quad \text { Area of study site }\left(\mathrm{m}^{-2}\right) \text {. }
\end{aligned}
$$

\section{II.3 Statistic analysis}

Analysis of variance was performed to know the difference of $T$. hemprichii growth of both observation stations. Then continuing with Pearson correlation analysis to know closeness of the relationship between environmental parameters and growth rate in each observation period. Data were analyzed with the SPSS programe. 


\section{RESULTS AND DISCUSSION}

\section{III.1 Growth}

The growth rate of $T$. hemprichii during each period (weeks) of observation could be seen in Figure 2. The growth rate ranged from $0.35 \pm 0.43$ to $0.46 \pm 0.53$ $\mathrm{cm}$ day $^{-1}$ with an average of $0.41 \pm 0.05$ (St 2) and $0.27 \pm$ 0.45 to $0.33 \pm 0.55 \mathrm{~cm}$. day $^{-1}$ with an average of $0.30 \pm$ $0.04 \mathrm{~cm}^{-d_{a y}{ }^{-1}}$ (St 1). Azkab and Kiswara [8], reported that the growth rate of $T$. hemprichii seagrass leaves in Teluk Kuta, South Lombok at $0.45 \mathrm{~cm}^{-d_{a y}{ }^{-1}}$ and this value was not much different from the results of this study. While Amiryati et al [9], found the growth rate of T. hemprichii in Rebong Pereh village, Bintan ranged from 0.11 to $0.25 \mathrm{~cm}_{\text {day }}{ }^{-1}$. This value is lower than the results of this study. This indicated that the growth of $T$. hemprichii seagrass of the Suli coastal waters is good.

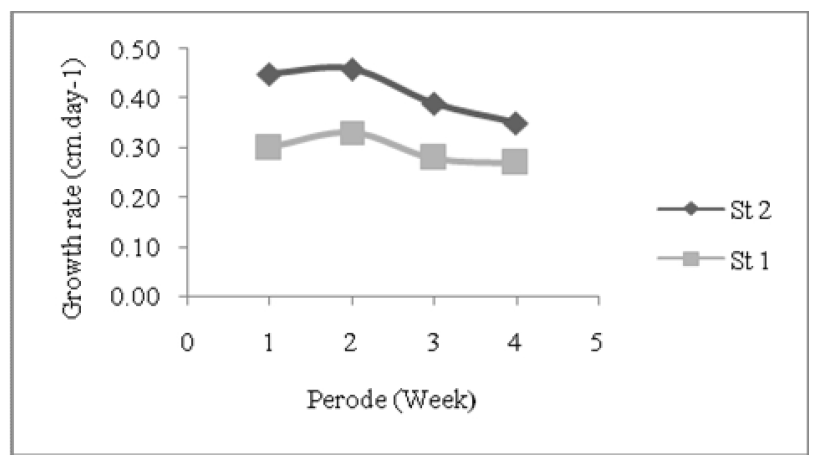

Figure 2. Growth rate of T. hemprichii on Suli coastal waters

Figure 2 displayed that the leaf growth rate increased in the first and second weeks, then decreased at week 3 and 4 at the two observation stations. This indicated that the efficiency of seagrass growth would decrease with the age of the leaves of seagrass. Young leaves were more active in length growth thought to be associated with relatively good tissue compared to old leaves [10]. Tupan \& Uneputty [11], reported that morphology of $T$. hemprichii seagrass leaves on sandy substrate (St 2) is larger than the muddy substrate (st 1). According to Erftemeijer and Middelburg [12], that the leaves of the seagrass before death will first move the nutrient to the leaf that is actively growing and the activity of photosynthesis will decrease when the leaves grow older.

The result of variance analysis showed that there was a significant difference between growth rate at both stations with $\mathrm{P}<0.001(\alpha=0.05)$. Leaf growth rate is higher at station 2 (Sandy substrate) than station 1 (muddy substrate). According to Erftemeijer and Middelburg [12], the smaller size of the sediment grains, the greater the availability of nutrients $\mathrm{N}$ and $\mathrm{P}$ on the substrate. So that, it would affect the growth of the seagrass which was getting high as well. However, this was different from the results of this study. The content of nitrate and phosphate was high at station 2 (sandy substrate) compared to station 1 (muddy substrates). This nutrient content would support the growth of seagrass. According to Supriadi [13], the growth of seagrasses was influenced by internal factors such as physiology and metabolism as well as external factors such as nutrients, substrate fertility and other environmental factors.
III.2 Production and Biomass

Production is the weight of new organic matter over a given period of time and with any loss during that period. Thus, production refers to the increased biomass observed at a certain period with any loss by respiration, excretion, secretion, grazing and death [14]. Production of $T$. hemprichii seagrass leaves ranged from 5.66 to 8.64 gADW.m. day $^{-1}$ (St 2) and 5.08 to 5.84 gADW.m day $^{-1}$ (St 1). Production was related to growth rate and density. High density and growth would produce high seagrass production as well. Station 2 showed higher production than station 1 . This was supported by the high growth and density of $T$. hemprichii seagrass at that station. Azkab and Kiswara [8], got the production of $T$. hemprichii seagrass leaves in the Kuta Bay, southern Lombok of $9.31 \mathrm{gADWm}^{-2} \mathrm{day}^{-1}$, and this value was higher than this study. Amiryati et al., [9], found the production of $T$. hemprichii leaf in Sebong Pereh village, Bintan at $2.44 \mathrm{gADWm}^{-2} \mathrm{day}^{-1}$, and this value was lower than this study.

The upper biomass (leaves and leaves sheaths) of $T$. hemprichii was obtained from 397 to $541 \mathrm{gADWm}^{-2}$ (St 2) and 245 to $330 \mathrm{gADWm}^{-2}$ (St 1). Biomass was the weight of all living material in a given area [14]. Biomass was related to seagrass density, so high density will increase biomass as well. The upper biomass obtained by Azkab and Kiswara [8] was 20.49 gADWm $^{-2}$ and by Amiyati et al., [9] of $312.80 \mathrm{gADWm}^{-2}$. The biomass of this study was quite high compared to both of previous results. 


\section{III.3 Environmental Parameters}

Water temperature has an indirect effect on photosynthesis, because some metabolic processes such as respiration and nutrient uptake are highly dependent on water temperatures [15]. During the study, the water temperature ranged from 30 to $31^{\circ} \mathrm{C}$, and was considered to be optimal temperature range for seagrass species [16]. Acording to Lobban et al., cited in Supriharyono [15], in moderate light conditions, most seagrasses have optimum temperatures for photosynthesis ranging from 25 to $35^{\circ} \mathrm{C}$. The very high temperatures can harm seagrass. Thalassia leaves will die at temperatures between 35 to $40^{\circ} \mathrm{C}$. Temperatures that are too low can also kill seagrasses in the tropics, for example the genus of Syringodium that grows in the Caribean, the leaves die at temperatures below $20^{\circ} \mathrm{C}$ [17].

The salinity values obtained during the study ranged from 30 to $35 \%$. According to Zieman [16], the optimum salinity for seagrass growth ranged from 25 to $35 \%$. Thus, the salinity obtained remains within the optimum salinity range for seagrass growth. Generally, salinity in the waters is always changing because it is influenced by various factors, among others such as the pattern of water circulation, evaporation, rainfall and fresh water supply from the river [18]. Decreasing salinity would decrease the ability of photosynthetic of the seagrass. Meanwhile, increasing salinity due to lack of freshwater supply can cause seagrass damage. The genus of Thalassia has a high tolerance to salinity of 10 to $50 \%$ [2].

The values of acidity $(\mathrm{pH})$ during the study ranged from 7 to 8. According to Phillips and Menez [17], the optimum acidity $(\mathrm{pH})$ for seagrass growth ranged from 7.3 to 9.0 . This indicated that the $\mathrm{pH}$ range during the study included the optimum value for seagrass growth and good for supporting marine life based on seawater quality standard specified in KEPMEN LH. No. 51 which ranged from 7 - 8.5 [19].

All living organisms require dissolved oxygen (DO) for breathing, metabolic processes and exchange of substances which then produce energy for growth and reproduction and for the oxidation of organic and inorganic materials in aerobic processes [20]. Dissolved oxygen is the dissolved oxygen content in the waters which is a major component of the metabolism of aquatic organisms used for the growth, reproduction, and fertility of seagrasses. The value of dissolved oxygen content (DO) of seagrass beds generally fluctuates. The dissolved oxygen content in a waters is thought to be due to the use of oxygen dissolved by seagrasses for respiration of roots and rhizomes, respiration of aquatic biota and use by nitrifying bacteria in the process of nitrogen cycle in seagrass beds [21]. The content of dissolved oxygen during the study on the Suli coastal waters ranged from 6.27 to $7.13 \mathrm{mgL}^{-1}$. This range of values was within the normal range so that the waters are well-determined based on the value of dissolved oxygen according to KEPMEN LH. No. 51 [19], about sea water quality standard that is $>5 \mathrm{mgL}^{-1}$.

Seagrasses obtain nutrients through roots and leaves. The absorption of nutrients in the water column was done by the leaves while the absorption of nutrients from the sediments was carried out by the roots and rhizomes [15]. Based on the results of research the content of nitrate and phosphate in the water column was lower than that in the sediments (Table 1). According to Erftemeijer and Middleburg [12], in tropical concentrations the nutrient concentrations dissolved in waters are lower than the concentrations of nutrients present in the sediments. This was because the nitrate waters were soluble, thus being easily transported by tidal and receding or current. While on the substrate was submerged so it was not easily carried away by the current.

The environmental parameters affecting the growth rate of $T$. hemprichii based on Pearson correlation analysis were nitrates and phosphate content in water and in sediments. In environmental conditions during the study at four periods of observation, the environmental parameters of nitrate and phosphate were positively correlated with growth rate. The high content of nitrate and phosphate will cause a high growth rate as well. According to Phillips and Menez [17], the source of nitrogen for the growth of seagrasses, among others, comes from recycling nitrogen in sediments, nitrogen from water column and nitrogen fixation. Dead seagrass rhizomes and roots add nitrate and nitrite content in the sediments. Therefore, the main source of nitrogen for leaf growth is recycled nitrogen derived from sediments. Supriadi et al., reported that seagrass growth is not limited by nitrogen when high nitrogen fixation rates and large ammonium concentrations [13]. On the contrary, high seagrass density and low concentrations of organic matter cause nitrogen to be a limiting factor for seagrass growth. 
Table 1. Content of Nitrate and phosphate on the location research

\begin{tabular}{|c|c|c|c|c|}
\hline \multirow{2}{*}{ Station } & \multicolumn{2}{|c|}{ Nitrate (mg.L-1) } & \multicolumn{2}{|c|}{ Phosphate (mg.L-1) } \\
\hline & Water & sediment & water & sediment \\
\hline 1 & $0.020 \pm 0.00$ & $0.057 \pm 0.00$ & $0.016 \pm 0.00$ & $0.280 \pm 0.00$ \\
\hline 2 & $0.061 \pm 0.06$ & $0.183 \pm 0.22$ & $0.020 \pm 0.01$ & $0.330 \pm 0.25$ \\
\hline
\end{tabular}

\section{CONCLUSION}

The growth of $T$. hemprichii is faster at the beginning of growth. The growth, production and biomass of the seagrass are higher in sandy substrates. The growth rate of $T$. hemprichii leaves is strongly influenced by nitrate and phosphate content of waters and sediments.

\section{ACKNOWLEDGEMENTS}

The study was funded by a research grant under the scheme Excellent Fundamental Research for Institution. The authors were greatly acknowledged the DP2M Higher Education.

\section{REFERENCES}

[1] M. D. Fortes, Seagrasses: A Resource Unknown in the ASEAN Region. ICLARM Education Ser 5. International Center for Living Aquatic Resources Management, Manila, Philippines, $1989,361 \mathrm{pp}$

[2] C. P. McRoy and McMillan, Production ecology and physiology of seagrass, In McRoy, C. P \& Helfferrich (Eds). Seagrass ecosystem, a scientific perspective. Marcel Dekker, Inc. New York, 1977

[3] V. C. Sinmiasa, "Status Keberlanjutan Komunitas Lamun di Perairan Pesisir Negeri Suli Kecamatan Salahutu Maluku Tengah”. Tesis. Universitas Pattimura. Ambon, 2015

[4] J. C. Zieman, Methods for the Study of the growth and production of turttle grass Thalassia testudinum Kinig. Aquaculture 4, 1974, Pp. 139-143

[5] F. T. Short and C. M. Duarte, Methods for the measurement of Seagrass growth and production. Pp.155-180. In Short, F. T \& Coles, R. G (ed), Global seagrass research methods. Elsevier Science B.V. Netherlands, 2001

[6] M. H. Azkab, Pedoman Invetarisasi Lamun. Oseana 1, 1999, pp. 1-16. Balitbang Biologi Laut, Pustlibang Oseanologi -LIPI, Jakarta.

[7] F. T. Short and R. G. Coles, "Global seagrass research methods". Elsevier Science B.V. Netherlands, 2001

[8] M. H. Azkab and W. Kiwara, Pertumbuhan dan produksi lamun di Teluk Kuta, Lombok Selatan. Dalam Struktur Komunitas Biologi Padang Lamun di Pantai Selatan Lombok dan Kondisi Longkungannya (Kiswara, W., Moosa, M. K. \& Hutomo, M, Eds). Pusat Penelitian dan Pengembangan Oseanologi. LIPI. Jakarta. 1994, pp. 34-41

[9] N. D. Amiyati, D. Azizah and T. Apriadi, Pertumbuhan dan produksi biomassa daun Thalassia hemprichii pada ekosistem padang lamun di perairan Desa Sebong Pereh, Bintan. Jurnal Umrah. 2016, 11p

[10] I. N. Sudiarsa, "Analisis Struktur Komunitas dan Produktivitas Lamun di Perairan Pulau Lima Kelapa, Teluk Banten”. Tesis. Universitas Terbuka. Jakarta, 2012.

[11] Ch. I. Tupan and Pr. A. Uneputty, The growth and population dynamics of seagrass Thalassia hemprichii in Suli Waters, Ambon Island. IOP Conference Series. Earth and Environmental Science 89 (2017) 012008

[12] P. L. A. Erftemeijer dan J. J. Middleburg, Sediment-nutreint interactions in tropical seagrass beds: a comparison between a terrigenous and a carbonate sedimentary environment in South Sulawesi (Indonesia). Marine Ecology Progress Series 102, 1993, pp. $187-198$
[13] Supriadi, D. Soedharma and R. F. Kawwadji, Beberapa aspek pertumbuhan lamun Enhalus acoroides (Linn.F) Royle di Pulau Barrang lompo Makassar. Biosfera 23 (1). 2006, Pp. 1-8

[14] M. H. Azkab, Produktivitas di Lamun. Oseana XXV (1), 2000, pp. 1-11. Balitbang Biologi Laut, Pustlibang Biologi Laut-LIPI, Jakarta.

[15] Supriharyono, "Konservasi Ekosistem Sumberdaya Hayati. Di wilayah pesisir dan laut tropis". Pustaka Pelajar. Yogyakarta, 2007

[16] J. C. Zieman, Seasonal variation of turtle grass, Thalassia testudinum Kinig, wih reference to temperature and salinity effect. Aquat. Bot 1 (2). 1975, Pp 107-124

[17] R. C. Phillips and E. G. Menez, "Seagrasses". Smithsonion Institution Press. Washington DC, 1988.

[18] J. W. Nybakken, "Biologi Laut. Suatu Pendekatan Ekologis". PT Gramedia. Jakarta, 1992.

[19] Menteri Negara Lingkungan Hidup. Keputusan Menteri Lingkungan Hidup No 51 Tahun 2004 Tentang Baku Mutu Air Laut.

[20] Salmin, Oksigen terlarut dan kebutuhan oksigen biologi (BOD) sebagai salah satu indikator untuk menentukan kualitas perairan. Oceana XXX (3), 2005, Pp 21-26

[21] P. Felisberto, S. M. Jesus, F. Zabel, R. Santos, J. Silva, S Gobert, S. Beer, M. Björk, S. Mazzuca, G. Procaccini, J. W. Runcie, W. Champenois and A. V. Borges, Acoustic Monitoring of $\mathrm{O}_{2}$ Production of a Seagrass Meadow. Journal of Experimental Marine Biology and Ecology. 464, 2015, Pp.7587 